\title{
The Path towards Planetary Responsibility - Expanding the Domain of Human Responsibility Is a Fundamental Goal for Lifelong Learning in a High-Consumption Society
}

\author{
Arto O. Salonen ${ }^{1} \&$ Mauri K. Åhlberg ${ }^{2}$ \\ ${ }^{1}$ Faculty of Welfare and Human Functioning, Helsinki Metropolia UAS, Finland \\ ${ }^{2}$ Faculty of Behavioral Sciences, University of Helsinki, Finland \\ Correspondence: Arto O. Salonen, Faculty of Welfare and Human Functioning, Helsinki Metropolia UAS, PO \\ Box 4032, FI-00079 Metropolia, Finland. Tel: 358-20-783-5000. E-mail: arto.salonen@gmail.com
}

Received: May 30, 2012 Accepted: July 5, 2012 Online Published: July 13, 2012

doi:10.5539/jsd.v5n8p13 URL: http://dx.doi.org/10.5539/jsd.v5n8p13

\begin{abstract}
How can we ensure a safe and just operating space for humanity? How to maintain the current human capabilities and opportunities and to support their expansion so that future generations will have the same capabilities and freedom as we do? Finnish university students $(\mathrm{n}=210)$ assessed 36 statements about environmental, social and economic sustainability according to the importance and actual implementation of the items in their daily life. They also made 464 comments about barriers to sustainable way of living. The data were analyzed with quantitative and qualitative methods. The results show that there is an attitude-behavior gap between every single assessed item of sustainable development. Overcoming the largest identified gaps calls for planetary responsibility. The most important and fundamental target for lifelong learning is to expand the domain of human responsibility to cover people, animals and other organisms, plants, and life-supporting ecosystems as well as natural resources of the planet Earth. This planetary responsibility requires a holistic vision consisting of changes in worldviews, ways of thinking, well-being paradigms and life orientations.
\end{abstract}

Keywords: sustainable development, attitude-behavior gap, planetary responsibility, behavior change

\section{Background}

The increase in individualism is the biggest cultural change that we have faced in the last few decades in the world (Hofstede et al., 2010). This change is strongly linked to the state of being separated from society and a lack of solidarity (Ginsborg, 2005), which means that our sentiments of mutual belonging and shared responsibility for a common future have weakened (Bauman, 2008). Individual consumerism has been a marked global trend. This is associated with each person's own interests and material life goals (Kasser, 2011).

The quality of development has been extensively questioned because inequality has grown and the vitality of life-supporting services that natural ecosystems provide has declined. Currently, curbing materialistic consumerism is seen as more important than population control (e.g. Assadourian, 2012). The population is projected to reach 9-10 billion in 2050, and it will remain approximately the same in 2100 (Engelman, 2009; UN, 2011).

In the current global age, whatever happens in one place influences the lives and life changes of people in other places. Our interconnections and interdependence are global (Bauman, 2008; Nussbaum, 2010). This means that we need more and more equality, which is one ideal of collective cultures (Hofstede et al., 2010). The richest 20 percentile of the world's population (1.4 billion people) consume over 80 percent of global output, or 60 times more than the poorest 20 percentile (Munasinghe, 2011). According to Stiglitz, Sen and Fitoussi (2009), high-consumption societies are "robbing future generations". We live in a global society of consumers in which ethical demands have too often been sacrificed for economic growth (Bauman, 2008; Bowels, 2008). Poorer countries, however, have the unconditional right to reach higher standards of living to fulfill their citizen's basic needs in the spirit of the Universal Declaration of Human Rights.

Sustainability and responsibility are linked. The future of the planet Earth is in our hands because we have power over the poorest of poor people, animals, plants and ecosystems. A very basic question is how to maintain the 
current human capabilities and opportunities and to support their expansion so that future generations will have the same capabilities and freedom as we do - or even more (Sen, 2009). In other words, how can we ensure a safe and just operating space for humanity (Raworth, 2012)?

In this research we are interested in understanding how sustainability is manifested in daily life in a high-consumption society. We want to find how environmental, economic and social goals are integrated into Finnish university students' everyday lives. One specific focus is on barriers to sustainable development. Understanding of the barriers helps us to define goals for lifelong learning.

In this article we start by describing Paul Stern's integrated Attitude-Behavior-Context (ABC) theory and by summing up how we apply $\mathrm{ABC}$ theory in our measurement instrument. From there, we move on to present of our study and its results. After that, we continue with a discussion about the implications of these results. We end this article by presenting fundamental goals for lifelong learning in transitioning towards a sustainable society.

\section{Attitudinal Variables, Contextual Factors and Behavior Change}

People justify their choices with relatively general and appropriate values based on the needs of individuals and communities (Schwartz, 1992). According to Hofstede et al. (2010), values are "feelings with an added arrow indicating a plus and a minus side". This definition is almost similar to Ajzen's definition of attitude. According to Ajzen (2005), attitude is an evaluative rating of an object (Ajzen, 2005). Attitude consists of beliefs and the evaluation of outcomes (Triandis, 1977). Thus, the conceptual difference between values and attitudes is slight.

Classical balance theories assume that human beings look for balance between their values, attitudes and behavior. According to Stern's (2000) integrated Attitude-Behavior-Context (ABC) theory (Figure 1), behavior is an interactive product of personal attitudinal variables and contextual factors. Behavior is neither fully deliberative nor fully automatic (Stern, 2000; Triandis, 1977).

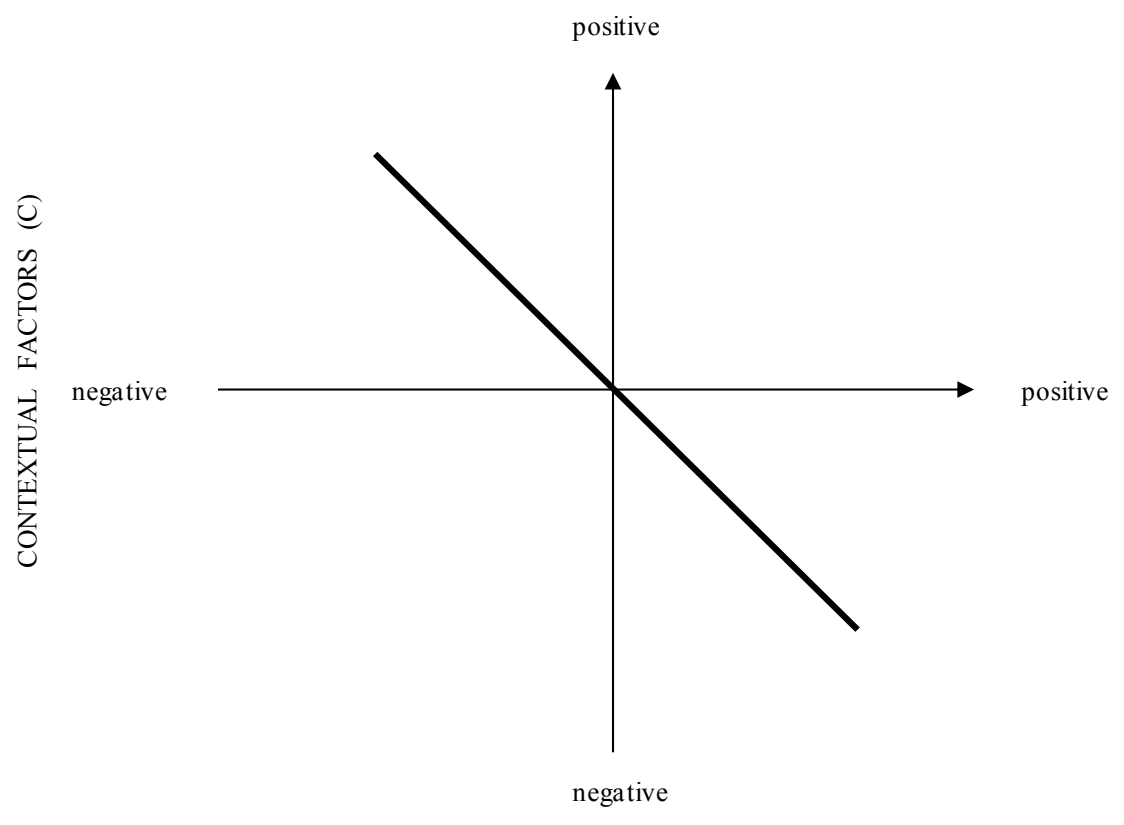

ATTITUDINAL VARIABLES (A)

Figure 1. Stern's integrated Attitude-Behavior-Context (ABC) theory

Attitudinal variables include a variety of specific personal beliefs, norms and values, the perceived costs and benefits of action as well as general pre-dispositions (abstract norms) to behave in a certain way (Stern, 2000; 2005). Attitudes are in the center of attempts to predict and explain behavior (Fishbein \& Ajzen, 2010). Behavior change is more probable if people believe that the benefits of their new behavior are more significant than its harmful effects (Weinreich, 1999). A gap between attitudes and behavior has been identified in several studies (e.g. Blake, 1999; Diekmann \& Preisendörfer, 2003; Kollmuss \& Agyeman, 2002). 
Contextual factors (facilitations, constraints) consist of a variety of influences such as convenience, monetary incentives and costs, and physical capabilities. Contextual factors also include institutional and legal factors, public policy support, as well as social norms and expectations (Stern, 2000; 2005). According to Barnett et al. (2011) "people don't necessarily lack information about fair trade, organic food, environmental sustainability or Third World sweatshops. They actually seem very aware of these types of things, but they often do not necessarily feel that they have the opportunities or resources to be able to engage in alternative consumption activities".

The dynamics between the influence of attitudes and contextual factors is a key dimension of the ABC theory. According to the $\mathrm{ABC}$ theory, the attitude-behavior link is strongest when contextual factors are weak, and the link between attitudes and behaviors is weak when contextual factors are either strongly negative or strongly positive (Jackson, 2005). According to Stern (2005), "interventions in the context are often more effective than directly targeting individuals with verbal appeals, information, or efforts to change attitudes or beliefs." Multiple influences on behavior usually offer the greatest potential for behavior change.

A sense of good and bad plays a role in decision making (Frank, 1992; Klöckner \& Preißner, 2006). Social groups determine what is "normal" for us. Due to social pressure, we often want to be loyal to these groups even if being "normal" is e.g. ecologically or socially an irresponsible way of acting (Barnett et al., 2011). Therefore, our morals guide as in how we balance the things that we value and what we implement in daily life.

Common morality is based on two ancient but still adequate imperative rules: "treat everyone fairly" and "always prevent harm" (Shafer-Landau, 2010). People are free, but also responsible for other people's vitality, self-esteem, dignity and resilience. Both freedom and responsibility are needed. In the framework of sustainability, this means that people are free to act but that they also have to ensure that other people and future generations will have equal or better opportunities than them. In the globalized world social justice extends beyond people who are physically related in our life, including those who are a part of the causal chains of producing and consuming.

Our responsibility should also cover non-human realities, such as ecosystem services. This is essential because human life is totally dependent on the non-human reality. In our daily life we need several necessities offered by life-supporting ecosystem services for free. These include e.g. fruitful soil, clean water, the pollination of plants and the decomposition of organic waste.

In addition, our material well-being is based on abiotic raw materials mined from nature, often far from us. In the globalized world, our mutual dependency is planet-wide, and we are responsible for one another and for all the causal chains that relate to human well-being. This planetary responsibility is both an environmental and social issue. An ecosystem-centered worldview combines these dimensions of responsibilities because it sees the planet Earth as a single community. Members of that community are bound together through a complex network of interdependent relationships (Miller \& Spoolman, 2009).

Figure 2 shows how we apply $\mathrm{ABC}$ theory in our measurement instrument. We assume that if an action is important for us and if we feel that the barriers are easy to overcome, we behave accordingly. Our research questions are: (a) Is there an attitude-behavior gap between any of the 36 items of sustainable development? (b) What are the most significant attitudinal and contextual barriers to sustainable development in daily life? (c) How to overcome the identified obstacles and attitude-behavior gaps?

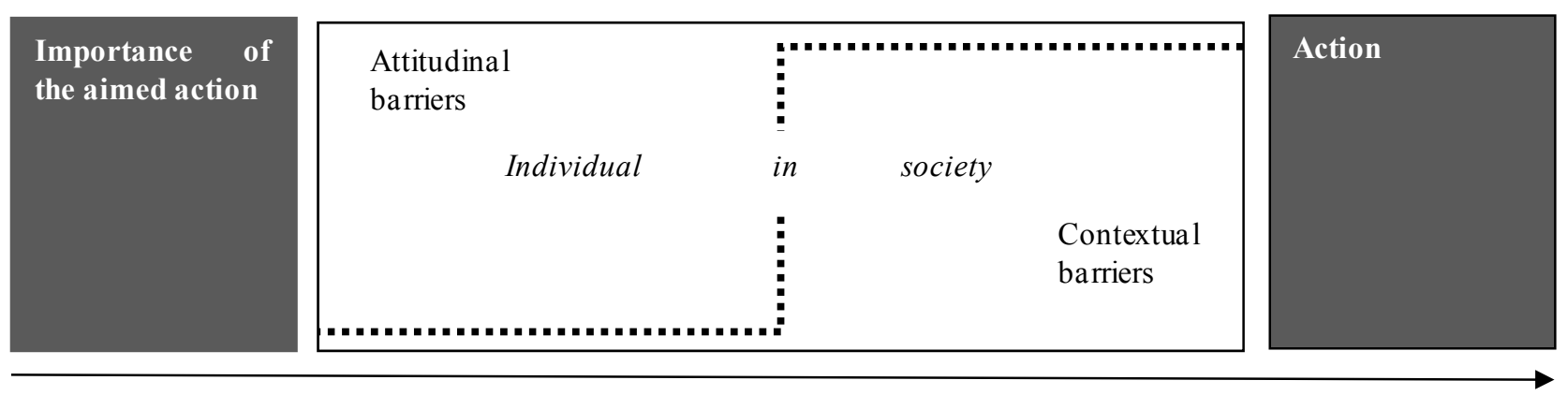

Figure 2. The importance of the aimed action and attitudinal and contextual barriers to the action 


\section{Methods}

The data were collected in 2008 and 2009. The sample consisted of Finnish university students $(\mathrm{n}=210)$. Their ages ranged from 18 to 40, and they lived in southern Finland.

The measurement instrument included variables of environmental, economic and social sustainability. Each of these three dimensions of sustainable development consists of 12 variables, and they were all evaluated by the respondents. The 36 variables were based on sustainable development strategies such as the Agenda 21 Environment and Development Programme (UN, 1992), the European Union Strategy for Sustainable Development (Council of the European Union, 2006), Agenda 21 for the Baltic Sea Region (Baltic 21, 1998), Sustainable Development - New Bearings for the Nordic Countries (Nordic Council of Ministers, 2009), and Towards Sustainable Choices - A Nationally and Globally Sustainable Finland (Prime Minister's Office, 2006). The following indicators were also taken into consideration: the Sustainable Society Index (van de Kerk \& Manuel, 2006), the Genuine Progress Indicator (Cobb et al., 2007), the Ecological Footprint (Wackernagel, 1994), the Wellbeing of Nations (Prescott-Allen, 2001) and the Happy Planet Index (Marks et al., 2006).

The respondents rated 36 statements of sustainable development with an eight-step (1-9) theoretical differential (Åhlberg, 1988, a modified semantic differential) according to their own attitudes and behavior with regard to

(a) the importance of the item (not important - extremely important) and

(b) their actions. The actual implementation of the item in the respondent's everyday life (not at all - always, perfectly).

These assessments formed the quantitative data. We calculated correlations of the importance and the actual implementation of the items. We also did paired samples $t$-test to identify statistical significance of possible gaps between attitude and behavior (Field, 2009).

The respondents were also asked to comment on their assessment freely. These comments created the data for the qualitative analysis. We used classical content analysis (Ryan \& Bernard, 2000; Patton, 2002). The aim was to obtain additional research material to interpret how the respondents think about the items that they rated. All the expressions that referred to barriers to behavior were quantified and classified. We formed the main classes according to the $\mathrm{ABC}$ theory.

\section{Identifying Attitude-Behavior Gaps and Barriers to Overcome}

The attitudinal factor scores for environmental, social and economic sustainability were systematically higher than the behavior scores. In all measured items of sustainable development, there were a statistically significant difference between the estimated importance and the actual implementation $(\mathrm{p}<0.000)$. Therefore, there was a gap between attitudes and behavior in every single assessed item of sustainable development (Table 1). 
Table 1. Paired samples test: the importance of the item and the actual implementation of the item

\begin{tabular}{|c|c|c|c|c|c|c|c|c|c|c|c|c|}
\hline & \multicolumn{2}{|c|}{ Importance } & \multicolumn{2}{|c|}{ Behavior } & \multicolumn{5}{|c|}{ Paired Differences } & \multirow{3}{*}{$\mathrm{t}$} & \multirow{3}{*}{ df } & \multirow{3}{*}{ Sig. } \\
\hline & \multirow[t]{2}{*}{ M } & \multirow[t]{2}{*}{ SD } & \multirow[t]{2}{*}{ M } & \multirow[t]{2}{*}{ SD } & \multirow[t]{2}{*}{ M } & \multirow[t]{2}{*}{ SD } & \multirow[t]{2}{*}{$\begin{array}{l}\text { Std. } \\
\text { Error } \\
\text { Mean }\end{array}$} & \multicolumn{2}{|c|}{$\begin{array}{l}95 \% \text { Confidence } \\
\text { Interval of the } \\
\text { Difference }\end{array}$} & & & \\
\hline & & & & & & & & Lower & Upper & & & \\
\hline 1. Local food & 6.87 & 1.7 & 4.24 & 1.9 & 2.63 & 2.1 & .146 & 2.34 & 2.91 & 18.01 & 209 & .000 \\
\hline 2. Vegetarian diet & 5.60 & 2.4 & 4.95 & 2.4 & .65 & 1.9 & .129 & .39 & .90 & 5.06 & 209 & .000 \\
\hline 3. Organic food & 7.52 & 1.8 & 3.94 & 1.8 & 3.57 & 2.1 & .142 & 3.30 & 3.86 & 25.17 & 209 & .000 \\
\hline $\begin{array}{l}\text { 4. Indoor temperature } \\
\text { max. } 21 \mathrm{C}\end{array}$ & 7.00 & 1.9 & 6.43 & 2.4 & .56 & 2.2 & .152 & .26 & .86 & 3.71 & 209 & .000 \\
\hline 5. Water conservation & 7.00 & 1.6 & 4.94 & 1.9 & 2.05 & 1.8 & .126 & 1.80 & 2.30 & 16.34 & 209 & .000 \\
\hline 6. Saving energy & 7.88 & 1.2 & 6.60 & 1.8 & 1.28 & 1.5 & .106 & 1.07 & 1.49 & 12.07 & 209 & .000 \\
\hline $\begin{array}{l}\text { 7. Use of renewable } \\
\text { energy sources in the } \\
\text { household }\end{array}$ & 7.66 & 1.6 & 2.91 & 2.3 & 4.75 & 2.6 & .180 & 4.39 & 5.10 & 26.43 & 209 & .000 \\
\hline 8. Recycling & 8.45 & .9 & 6.48 & 2.1 & 1.97 & 1.9 & .130 & 1.71 & 2.22 & 15.14 & 209 & .000 \\
\hline 9. Composting & 8.14 & 1.3 & 6.03 & 3.1 & 2.11 & 2.7 & .188 & 1.73 & 2.48 & 11.23 & 209 & .000 \\
\hline $\begin{array}{l}\text { 10. Taking care of } \\
\text { hazardous waste }\end{array}$ & 8.44 & 1.0 & 6.58 & 2.3 & 1.86 & 2.0 & .138 & 1.58 & 2.13 & 13.41 & 209 & .000 \\
\hline $\begin{array}{l}\text { 11. Favoring walking, } \\
\text { cycling and public transport }\end{array}$ & 8.18 & 1.1 & 7.39 & 2.0 & .80 & 1.8 & .125 & .54 & 1.04 & 6.38 & 209 & .000 \\
\hline $\begin{array}{l}\text { 12. Replacing goods and } \\
\text { equipment only when } \\
\text { broken }\end{array}$ & 7.35 & 1.5 & 6.35 & 1.9 & .99 & 1.5 & .104 & .79 & 1.20 & 9.55 & 209 & .000 \\
\hline 13. Thriving small business & 7.10 & 1.6 & 4.36 & 1.8 & 2.74 & 1.8 & .124 & 2.49 & 2.98 & 22.13 & 209 & .000 \\
\hline 14. Thriving local business & 7.18 & 1.6 & 4.81 & 1.9 & 2.37 & 1.9 & .128 & 2.11 & 2.62 & 18.48 & 209 & .000 \\
\hline $\begin{array}{l}\text { 15. Favoring products and } \\
\text { services of forefront } \\
\text { companies }\end{array}$ & 7.48 & 1.6 & 4.43 & 1.8 & 3.05 & 1.9 & .133 & 2.79 & 3.31 & 22.92 & 209 & .000 \\
\hline $\begin{array}{l}\text { 16. Quantity and type of } \\
\text { waste from product } \\
\text { manufacture }\end{array}$ & 6.90 & 1.9 & 3.90 & 2.0 & 3.00 & 2.1 & .146 & 2.70 & 3.28 & 20.50 & 209 & .000 \\
\hline $\begin{array}{l}\text { 17. Products that can be } \\
\text { repaired }\end{array}$ & 7.00 & 1.8 & 4.97 & 2.1 & 2.04 & 1.9 & .130 & 1.78 & 2.29 & 15.72 & 209 & .000 \\
\hline $\begin{array}{l}\text { 18. Product longevity and } \\
\text { durability }\end{array}$ & 8.20 & 1.2 & 6.76 & 1.8 & 1.44 & 1.6 & .111 & 1.22 & 1.66 & 13.03 & 209 & .000 \\
\hline $\begin{array}{l}\text { 19. Quality of the materials } \\
\text { in commodities }\end{array}$ & 7.02 & 1.7 & 4.45 & 1.9 & 2.57 & 1.8 & .126 & 2.32 & 2.82 & 20.40 & 209 & .000 \\
\hline $\begin{array}{l}\text { 20. Quantity and quality of } \\
\text { packaging }\end{array}$ & 7.87 & 1.3 & 5.35 & 2.0 & 2.52 & 1.9 & .128 & 2.27 & 2.77 & 19.70 & 209 & .000 \\
\hline 21. Product recyclability & 7.81 & 1.4 & 5.23 & 1.9 & 2.58 & 1.8 & .127 & 2.33 & 2.83 & 20.39 & 209 & .000 \\
\hline $\begin{array}{l}\text { 22. Favoring eco-labeled } \\
\text { products }\end{array}$ & 7.95 & 1.3 & 5.53 & 1.9 & 2.41 & 1.8 & .124 & 2.17 & 2.66 & 19.45 & 209 & .000 \\
\hline $\begin{array}{l}\text { 23. Energy efficiency in } \\
\text { product manufacture and } \\
\text { use }\end{array}$ & 6.71 & 2.0 & 3.66 & 1.9 & 3.05 & 2.1 & .146 & 2.75 & 3.33 & 20.83 & 209 & .000 \\
\hline $\begin{array}{l}\text { 24. Use of services instead } \\
\text { of ownership of goods }\end{array}$ & 6.80 & 1.9 & 4.67 & 2.1 & 2.13 & 2.0 & .141 & 1.85 & 2.40 & 15.05 & 209 & .000 \\
\hline $\begin{array}{l}25 \text {. Global poverty } \\
\text { reduction }\end{array}$ & 8.33 & 1.1 & 4.01 & 1.9 & 4.31 & 2.0 & .137 & 4.04 & 4.58 & 31.46 & 209 & .000 \\
\hline $\begin{array}{l}\text { 26. Social responsibility of } \\
\text { the consumer }\end{array}$ & 8.29 & 1.0 & 4.80 & 2.0 & 3.49 & 2.0 & .138 & 3.21 & 3.75 & 25.34 & 209 & .000 \\
\hline 27. Equality and tolerance & 8.47 & 1.1 & 6.63 & 1.8 & 1.84 & 1.6 & .113 & 1.61 & 2.06 & 16.24 & 209 & .000 \\
\hline 28. Communality & 8.61 & .7 & 6.40 & 1.7 & 2.21 & 1.7 & .115 & 1.98 & 2.43 & 19.14 & 209 & .000 \\
\hline $\begin{array}{l}\text { 29. Maintaining of civil } \\
\text { society }\end{array}$ & 8.03 & 1.2 & 5.45 & 1.9 & 2.58 & 1.8 & .124 & 2.33 & 2.82 & 20.78 & 209 & .000 \\
\hline 30. Social inclusion & 8.38 & .9 & 5.61 & 1.7 & 2.77 & 1.6 & .111 & 2.54 & 2.98 & 24.91 & 209 & .000 \\
\hline $\begin{array}{l}\text { 31. Health-promoting } \\
\text { lifestyle }\end{array}$ & 8.41 & .9 & 6.10 & 1.8 & 2.32 & 1.8 & .125 & 2.07 & 2.56 & 18.56 & 209 & .000 \\
\hline $\begin{array}{l}\text { 32. Elimination of public } \\
\text { health risks }\end{array}$ & 8.32 & 1.0 & 6.36 & 1.8 & 1.96 & 1.7 & .118 & 1.72 & 2.19 & 16.60 & 209 & .000 \\
\hline 33. Intergenerational link & 8.19 & 1.0 & 5.80 & 2.1 & 2.39 & 1.9 & .129 & 2.13 & 2.63 & 18.55 & 209 & .000 \\
\hline 34. Volunteering & 7.97 & 1.2 & 3.80 & 2.3 & 4.17 & 2.3 & .158 & 3.85 & 4.47 & 26.50 & 209 & .000 \\
\hline $\begin{array}{l}\text { 35. Use of study } \\
\text { opportunities }\end{array}$ & 7.92 & 1.1 & 6.27 & 1.9 & 1.65 & 1.8 & .126 & 1.40 & 1.89 & 13.10 & 209 & .000 \\
\hline $\begin{array}{l}\text { 36. Low value for } \\
\text { ownership }\end{array}$ & 7.76 & 1.5 & 5.83 & 1.7 & 1.92 & 1.5 & .104 & 1.72 & 2.13 & 18.48 & 209 & .000 \\
\hline
\end{tabular}

We calculated Pearson correlation coefficients between the attitudinal and behavioral factors (Table 2). Linear dependency was strong $(r>0.5)$ in the following three items: favoring vegetarian diets, replacing goods and 
equipment only when broken and giving low value for ownership. This means that these variables have over 25 percent shared variance between their estimated importance and implementation. With these three variables we have more confidence than with other measured items, that respondents who claim that they value these items also implement them in daily life.

Table 2. Pearson correlation coefficients between the attitudinal and behavioral factors and the means of estimated importance and implementation $(\mathrm{n}=210)$

\begin{tabular}{|c|c|c|c|c|}
\hline Evaluated item of sustainability & $\begin{array}{c}\text { Pearson's } \\
r\end{array}$ & $\begin{array}{l}\text { Mean of estimated } \\
\text { importance }\end{array}$ & $\begin{array}{c}\text { Mean of estimated } \\
\text { implementation }\end{array}$ & $\begin{array}{c}\text { Difference } \\
\text { between means }\end{array}$ \\
\hline 1. Vegetarian diet & .7 & 5.60 & 4.95 & .65 \\
\hline $\begin{array}{l}\text { 2. Replacing goods and equipment } \\
\text { only when broken }\end{array}$ & .6 & 7.35 & 6.35 & 1.00 \\
\hline 3. Low value for ownership & 6 & 7.76 & 5.83 & 1.93 \\
\hline $\begin{array}{l}\text { 4. Favoring products that can be } \\
\text { repaired }\end{array}$ & .5 & 7.00 & 4.97 & 2.03 \\
\hline 5. Saving energy & .5 & 7.88 & 6.60 & 1.28 \\
\hline 6. Taking care of hazardous waste & .5 & 8.44 & 6.58 & 1.86 \\
\hline 7. Indoor temperature max. $21 \mathrm{C}$ & .5 & 7.00 & 6.43 & 0.57 \\
\hline 8. Product longevity and durability & .5 & 8.20 & 6.76 & 1.44 \\
\hline $\begin{array}{l}\text { 9. Quality of the materials in } \\
\text { commodities }\end{array}$ & .5 & 7.02 & 4.45 & 2.57 \\
\hline 10. Water conservation & .5 & 7.00 & 4.94 & 2.06 \\
\hline 11. Thriving local business & .5 & 7.18 & 4.81 & 2.37 \\
\hline $\begin{array}{l}\text { 12. Use of services instead of } \\
\text { ownership of goods }\end{array}$ & .5 & 6.80 & 4.67 & 2.13 \\
\hline 13. Composting & .5 & 8.14 & 6.03 & 2.11 \\
\hline 14. Equality and tolerance & .4 & 8.47 & 6.63 & 1.84 \\
\hline $\begin{array}{l}\text { 15. Favoring walking, cycling and } \\
\text { public transport }\end{array}$ & .4 & 8.18 & 7.39 & .79 \\
\hline 16. Intergenerational link & .4 & 8.19 & 5.80 & 2.39 \\
\hline 17. Product recyclability & .4 & 7.81 & 5.23 & 2.58 \\
\hline 18. Thriving small business & .4 & 7.10 & 4.36 & 2.74 \\
\hline 19. Quantity and quality of packaging & .4 & 7.87 & 5.35 & 2.52 \\
\hline 20. Favoring eco-labeled products & .4 & 7.95 & 5.53 & 2.42 \\
\hline $\begin{array}{l}\text { 21. Energy efficiency in product } \\
\text { manufacture and use }\end{array}$ & .4 & 6.71 & 3.66 & 3.05 \\
\hline 22. Social inclusion & .4 & 8.38 & 5.61 & 2.77 \\
\hline 23. Recycling & .4 & 8.45 & 6.48 & 1.97 \\
\hline $\begin{array}{l}\text { 24. Quantity and type of waste from } \\
\text { product manufacture }\end{array}$ & .4 & 6.90 & 3.90 & 3.00 \\
\hline 25. Maintaining of civil society & .4 & 8.03 & 5.45 & 2.58 \\
\hline $\begin{array}{l}\text { 26. Favoring products and services of } \\
\text { forefront companies }\end{array}$ & .4 & 7.48 & 4.43 & 3.05 \\
\hline 27. Use of study opportunities & .3 & 7.92 & 6.27 & 1.65 \\
\hline 28. Elimination of public health risks & .3 & 8.32 & 6.36 & 1.96 \\
\hline 29. Organic food & .3 & 7.52 & 3.94 & 3.58 \\
\hline 30. Health-promoting lifestyle & .3 & 8.41 & 6.10 & 2.31 \\
\hline 31. Volunteering & .3 & 7.97 & 3.80 & 4.17 \\
\hline 32. Local food & .3 & 6.87 & 4.24 & 2.63 \\
\hline $\begin{array}{l}\text { 33. Social responsibility of the } \\
\text { consumer }\end{array}$ & .2 & 8.29 & 4.80 & 3.49 \\
\hline 34. Communality & .2 & 8.61 & 6.40 & 2.21 \\
\hline 35. Global poverty reduction & .2 & 8.33 & 4.01 & 4.32 \\
\hline $\begin{array}{l}\text { 36. Use of renewable energy sources in } \\
\text { the household }\end{array}$ & .1 & 7.66 & 2.91 & 4.75 \\
\hline
\end{tabular}


We identified only medium sized linear dependency $(\mathrm{r}<0.3)$ between attitudinal and behavioral factors in the use of renewable energy sources in the household, global poverty reduction, communality, and the social responsibility of the consumer. This means that these four variables have less shared variance between their estimated importance and implementation than other 32 variables. With these variables, we have less confidence that respondents who claim that they value these items also implement them.

We also calculated differences of the means the attitudinal and behavioral factors (Table 2). The widest gaps between the importance and implementation of the rated thing or phenomenon were identified in the use of renewable energy sources in the household (4.75), global poverty reduction (4.32), volunteering (4.17), organic food (3.58) and the social responsibility of the consumer (3.49). Only narrow gaps were identified in the adjustment of the temperature of one's home (0.65), favoring a vegetarian diet (0.65) and favoring walking, cycling and public transport (0.79) in daily life.

We quantified 464 expressions which refer to the obstacles to implementing the sustainable development principles in everyday life. Of these, 261 concerned attitudinal barrier and 203 of them contextual barrier (Table $3)$.

Table 3. Barriers to sustainable development in everyday life

\begin{tabular}{|c|c|c|}
\hline QUALITY OF BARRIER & frequency & $\%$ \\
\hline \multicolumn{3}{|l|}{ Attitudinal barriers } \\
\hline . lack of knowledge & 78 & 17 \\
\hline . lack of time & 63 & 13 \\
\hline . lack of convenience & 36 & 8 \\
\hline . different personal values, preferences or needs & 32 & 7 \\
\hline . conflict, suspicion & 29 & 6 \\
\hline . careless, impassive & 10 & 2 \\
\hline . personality does not support implementation & 6 & 1 \\
\hline . incompetence & 5 & 1 \\
\hline . other & 2 & $<1$ \\
\hline Attitudinal barriers, total & 261 & 56 \\
\hline \multicolumn{3}{|l|}{ Contextual barriers } \\
\hline . high costs & 118 & 25 \\
\hline . limited power to affect external living conditions & 44 & 9 \\
\hline - $\quad$ sustainable products or services are not available & 22 & 5 \\
\hline . design or quality of products is not sustainable & 9 & 2 \\
\hline . culture does not support sustainable way of life & 6 & 1 \\
\hline . other & 4 & $<1$ \\
\hline Contextual barriers, total & 203 & 44 \\
\hline Total & 464 & 100 \\
\hline
\end{tabular}

Attitudinal barriers. A lack of knowledge accounted for 17 percent of the analyzed obstacles. Knowledge is an important aspect of capability (Ajzen, 2005). After becoming informed people are ready to change their behavior if they are sure that a new way of behaving will prevent problems in the future (Weinreich, 1999).

A lack of time was the other significant attitudinal barrier to sustainable behavior which accounted for 13 percent of the mentioned obstacles. A lack of time is related to values, which can be prioritized. People usually have time for the things that they prioritize highly (Allardt, 1983; Kluckhohn \& Strodtbeck, 1961).

Inconvenience was the reason given for 8 percent of the attitudinal obstacles. The respondents also recognized situations where their own values, preferences or needs did not support sustainable development. This type of obstacles represented 7 percent of the barriers.

Contextual barriers. The high costs of sustainable products and services created the most significant barrier to sustainability. It represented 25 percent of all the obstacles. The high price of organic food was the highest barrier to overcome. The importance of costs was also clear when supporting local business and favoring of good quality product. In addition, high costs formed an obstacle to choosing sustainable consumption, particularly when evaluating whether to repair a product or not. 
The major role of costs has been verified in other studies. Swim et al. (2009) found that the most important factor in a decision situation is cost-effectiveness. Kollmuss and Agyeman (2002) argue that the share of the importance of costs in purchasing decisions is at least 50 percent. The mainstreaming of sustainability is easier when the price of product includes the environmental, social and economic costs formed during its life cycle (Hawken, 2010; Meadows et al., 2004).

Almost a tenth of the obstacles were related to the limited ability to affect one's external living conditions. 5 percent of the obstacles referred to a lack of sustainable products or services.

\section{Transitioning towards a Sustainable Society}

We identified a gap between attitudes and behavior in every single evaluated item of sustainable development. The attitude-behavior gap is characteristic of human beings. It seems that most people in the world relate to sustainable development principles positively but passively (Blake, 1999; Diekmann \& Preisendörfer, 2003; Jurin \& Fortner, 2002; Kollmuss \& Agyeman, 2002; Koskela, 2008). Despite this, our results show that Finnish students who value (a) vegetarian diets, (b) replacing goods and equipment only when broken, or (c) giving low value for ownership also behave accordingly. What we also found is that there is only a narrow attitude-behavior gap in (a) the adjustment of the temperature of one's home, (b) favoring vegetarian diets and (c) favoring walking, cycling and public transport. Transitioning towards a sustainable society is going on well with these factors of sustainability.

We identified the weakest correlations between respondents' attitudes and behavior in (a) the use of renewable energy sources in the household, (b) global poverty reduction, (c) communality and (d) the social responsibility of the consumer. The widest gaps between the importance and implementation of the rated thing were identified mainly in the same evaluated items: the use of renewable energy sources in the household (4.75), global poverty reduction (4.32), volunteering (4.17), organic food (3.58) and the social responsibility of the consumer (3.49).

In these factors the link between attitude and behavior is weak. According to $\mathrm{ABC}$ theory a solution is an intervention in the context. This means societal change which depends on decision makers who are responsible for laws and regulations, financial incentives and penalties. According to Jackson (2009), the role of governments is to provide the capabilities for its citizens to flourish within ecological limits. This is particularly important because humans are naturally behaviorally conservative, which means that we are creatures of habit (Rees, 2010). In a sustainable society, sustainable everyday choices are easy to implement, and socially and environmentally harmful choices are difficult to implement (Hawken et al., 2010).

As already mentioned, the gap between attitude and behavior was distinct in the use of renewable energy sources in the household. The respondents valued renewable energy sources highly. It seems to us that they understand that accelerating emissions are a threat to stable and flourishing societies. However, they did not switch to renewable energy in their households even though switching to renewable energy is relatively easy in households in Finland. A challenge of sustainability is more an attitudinal than contextual one in this case.

We identified that typical barrier to overcome was lack of knowledge due to impassiveness: "I do not know the energy source of my household (29)". This raises an ethical dilemma particularly as energy produced by fossil fuels will lead to irreversible changes on the Earth (IEA, 2009; 2011). Energy solutions are linked to ecological integrity, the safeguarding of biodiversity, democracy, nonviolence and peaceful co-existence among people. Emissions and climate change also have strong negative effects on human health and nutrition, especially in developing countries (DARA, 2010; Epstein et al., 2011; Markandya \& Wilkinson, 2007; Sale, 2011; UNDP, 2008; Wheeler, 2011). Maybe we have a reason to ask if it is against the Human Rights to burn fossil fuels. The present social costs of carbon dioxide are approximately 900 dollars per ton. This means that "almost anything that reduces emissions is worth doing" (Ackerman \& Stanton, 2011). We need to be informed and we need a wider life orientation in which we understand that human beings are part of the fragile planetary entity. Renewable energy is good for humans and it is also good for nature.

The link between attitude and behavior was weak in both global poverty reduction and the social responsibility of the consumer. These factors refer to ethics, awareness and consciousness. In the globalized world forced labor, child labor, inhuman working conditions and extremely low salaries at manufacturing plants are linked to our everyday commodities (e.g. Bertrand, 2011; Coninck et al., 2011; Goleman, 2009; Iqbal et al., 2012; Reardon, 2012; U.S. Department of Labor, 2009).

We identified both attitudinal and contextual barriers to overcome. Some respondents felt that their power to make difference in their daily life is limited: "I want to make a difference but I feel that I cannot (160)." This obstacle refers to circumstances. Some of the respondents highlighted that they live in an interdependent world: 
"What will happen if everybody has the possibility to live a lavish life on planet Earth (196)?" This refers to geographical, intergenerational and intra-generational equity or inequity (Haughton, 1999). Respondents also identified conflicting results in decision making: "No information, prices have an impact on my behavior, boycotts are discussed (162)." This is good news because uncertainty is the only soil in which morality can flourish (Bauman, 2008).

The great distance between the producer and consumer has decreased our responsibility and solidarity. This demands that we expand our moral circle (Hofstede et al., 2010; Wenz, 1988). Through an emotional education, we "learn to identify with the lot of others, to see the world through their eyes, and feel their suffering vividly through the imagination" (Nussbaum, 2010, 40). This is how others become equal and real to us.

The large gap between attitude and behavior was also identified in favoring organic food. It is important to try to close this gap because there is evidence that agricultural chemicals used in factory farming - synthetic fertilizers, pesticides and herbicides - threaten the entire foundation of world food production and decrease biodiversity (Balmford et al., 2008; BirdLife, 2008; Nellemann et al., 2009; Reganold, 2010). In contrast, organic farming helps to combat climate change, because it requires less energy than industrialized agriculture. It also absorbs more carbon dioxide than factory farming (LaSalle \& Hepperly, 2008) and increases the sense of community and the vitality of the country-side due to farmers' sharing of the knowledge and skills necessary for successful organic farming (Herren, 2011; Lobley et al., 2009).

The major obstacle to sustainable organic food was its high cost. This barrier refers to the external living conditions. The overall challenge is that the prices of our daily commodities do not adequately account for their environmental and social costs (Dauvergne, 2008). This means that it is difficult to compare different products and services in the framework of sustainability.

Importance of community was rated higher than any other item of sustainability. Respondents understand a value of the renewed sense of community and cooperative relationships. They want greater and more fulfilling interactions with friends and neighbors, and more opportunities to express their creativity. According to our analysis, there was a large attitude-behavior gap in volunteering. Community and volunteering is a way to enhance altruism - the willingness to care for one another's well-being. It integrates the elderly, young people, immigrants or people with disabilities, supports participation and social inclusion in society and empowers individuals (Bauman, 2008; Commission of the European Communities, 2009).

The most important obstacle to volunteering was the lack of time. We identified the very same barrier to the nurturing of community. The Finnish respondents live in an individual-oriented high-consumption society where people are competing with each other. A speed of life is high. The pursuit of material prosperity is prioritized more highly than the nurturing of harmony and common wealth. The importance of economic growth is argued by citizens to be more essential now than some years ago (Haavisto \& Kiljunen, 2011). However, thinking like an economist undermines community (Marglin, 2008). Even if individualism and atomist thinking correlates with an accumulation of material goods (Hofstede et al., 2010; Laszlo, 1996), it is an unsustainable way to achieve subjective well-being because even though we work harder and harder, we never seem to get anywhere (Haque, 2011; Kahneman et al., 2006). The pursuit of happiness demands us to adopt a more community based life orientation (Graham, 2011).

We are individuals in society. Both societal change and individual behavior change is needed to achieve the goal of sustainability. Sustainable development efforts should involve everyone everywhere (Filho, 2011). Our planet is not a collection of discrete phenomena and events, but a system of the interdependence. All past, present and future forms of life are connected (Miller \& Spoolman, 2009). For example, the echoes of the earliest human-caused carbon emissions are still present in our atmosphere (Pongratz \& Caldeira, 2012). Systems thinking is needed to see the earth as a single community.

Lifelong learning can improve knowledge, skills and competence within a personal, civic and social perspective. A transition towards a sustainable society is powerful if education produces a critically thinking person who is able to synthesize the rich information about the wide range of world situations. More often this means competing factors, conflicting results, and tolerating compromises. However, uncertainty is the home ground of the moral person (Bauman, 2008). On this ground we are able to display a robust ability to imagine the predicaments of many types of people and to think reflectively (Nussbaum, 2010).

\section{A Fundamental Goal for Lifelong Learning in a High-Consumption Society}

Sustainability is an existential challenge. It is linked to what we believe about what is right and what is wrong in our behavior. We need both individual behavior change (attitudes) and societal change (context) to achieve the 
goal of sustainability in high-consumption societies. This change highlights human solidarity and expanding of moral circle in order to create a safe and just operating space for humanity. Therefore, we argue that the most important and fundamental target for lifelong learning is to expand the sphere of human responsibility to cover people, animals and other organisms, plants, and life-supporting ecosystems as well as natural resources of the planet Earth. This planetary responsibility requires a holistic vision consisting of changes in worldviews, ways of thinking, well-being paradigms and life orientations (Table 4).

Table 4. A path towards planetary responsibility

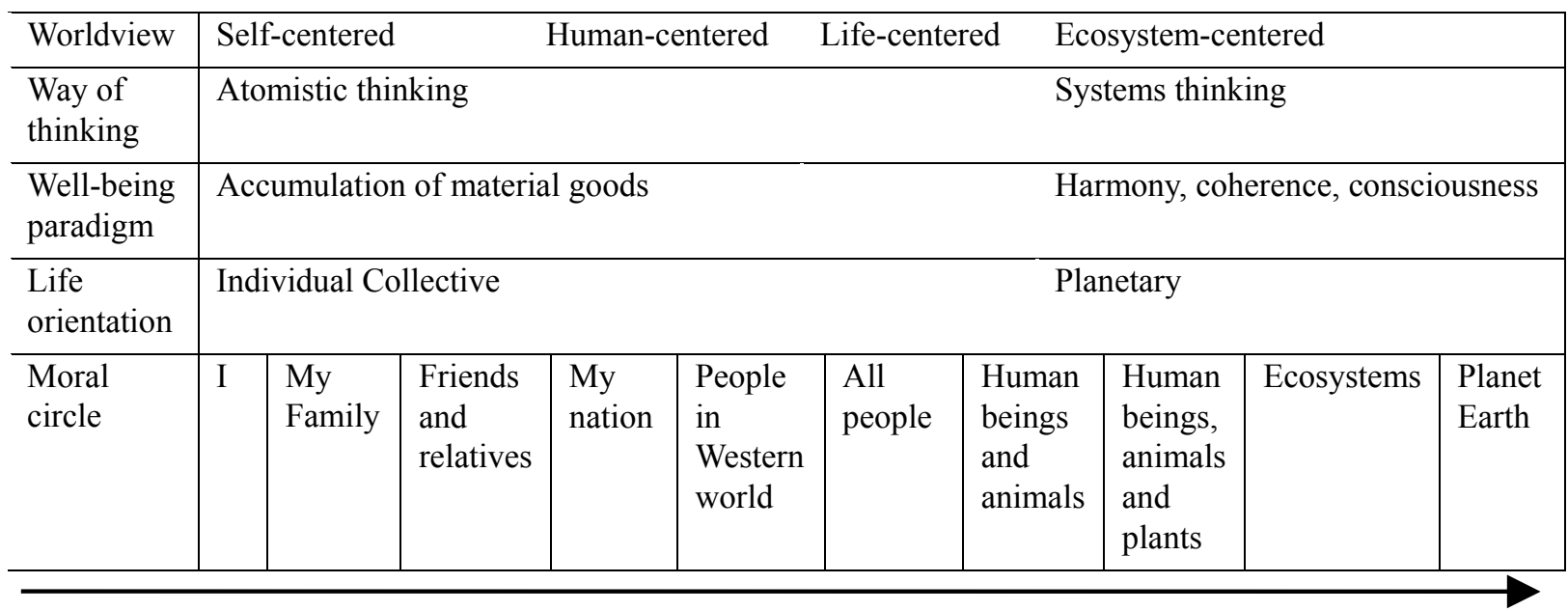

\section{References}

Ackerman, F., \& Stanton, E. A. (2011). Climate Risks and Carbon Prices: Revising the Social Cost of Carbon. Somerville: Stockholm Environment Institute-US.

Åhlberg, M. (1988). Kasvatustavoitteiden teoreettinen kehikko ja sen empiiristä koettelua. (Theoretical framework for educational objectives and its empirical testing). University of Helsinki. Department of Education. Tutkimuksia (Research reports) no 117. (Doctoral dissertation).

Ajzen, I. (2005). Attitudes, personality, and behaviour. London: McGraw-Hill.

Allardt, E. (1983). Sosiologia I. (Sociology I). Helsinki: WSOY.

Assadourian, E. (2012). The Path to Degrowth in Overdeveloped Countries. In Erik Assadourian \& Michael Renner (Eds.), State of the World 2012: Moving Toward Sustainable Prosperity (pp. 22-37). Washington: Island Press.

Balmford, A., Naidoo, R., Costanza, R., Fisher, B., Green, R., Lehner, B. ... Ricketts, T. H. (2008). Global mapping of ecosystem services and conservation priorities. PNAS, 105(28), 9495-9500. http://dx.doi.org/10.1073/pnas.0707823105

Baltic 21. (1998). Indicators on sustainable development in the Baltic Sea region. Series No 13/1998. Retrieved from www.baltic21.org/attachments/report_no_13_98_indicators.pdf

Barnett, C., Cloke, P., Clarke, N., \& Malpass, A. (2011). Globalizing Responsibility: The Political Rationalities of Ethical Consumption. Oxford: Wiley-Blackwell.

Bauman, Z. (2008). Does Ethics Have Change in a World of Consumers? Cambridge: Harward University.

Bertrand, W. (2011). Final Report - Oversight of Cocoa Industry in Ghana and Ivory Coast. Payson Center at Tulane University 2011. Retrieved from http://www.childlabor-payson.org/

Blake, J. (1999). Overcoming the value-action gap in environmental policy: Tensions between national policy and local experience. Local Environment, 4(3), 257-278. http://dx.doi.org/10.1080/13549839908725599

BirdLife. (2008). Critically endangered birds - A global audit. Cambridge: BirdLife International.

Bowels, S. (2008). Policies designed for self-interested citizens may undermine the moral sentiments: Evidence from economic experiments. Science, 320(20), 1605-1609. http://dx.doi.org/10.1126/science.1152110 
Cobb, C., Slattery, N., \& Talberth, J. (2007). The genuine progress indicator 2006. A tool for sustainable development. San Francisco: Redefining Progress.

Commission of the European Communities. (2009). Proposal for a on the European Year of Volunteering (2011). SEC(2009)725. Retrieved

from http://eur-lex.europa.eu/LexUriServ/LexUriServ.do?uri=COM:2009:0254:FIN:EN:PDF

Coninck, N., Theuws, M., \& Overeem, P. (2011). Captured by Cotton. Exploited Dalit girls produce garments in India for European and US markets. Amsterdam: SOMO - Centre for Research on Multinational Corporations. Retrieved from www.indianet.nl/pdf/CapturedByCotton.pdf

Council of the European Union. (2006). European Commission Renewed EU sustainable strategy. (OR. en) 10917/06. Retrieved from http://ec.europa.eu/sustainable/docs/renewed_eu_sds_en.pdf

DARA. (2010). The Climate Vulnerability Monitor 2010. The State of the Climate Crisis. 2010 report of the Climate Vulnerability Initiative. Dara and the Climate Vulnerable Forum. Retrieved from $\mathrm{http}$ ://daraint.org/climate-vulnerability-monitor/climate-vulnerability-monitor-2010/download-the-report/

Dauvergne, P. (2008). The shadows of consumption. Consequences for the global environment. Cambridge: MIT, 2008.

Diekmann, A., \& Preisendörfer, P. (2003). Green and Greenback. The Behavioral Effects of Environmental Attitudes in Low-Cost and High-Cost Situations. Rationality and Society, 15(4), 441-472. http://dx.doi.org/10.1177/1043463103154002

Engelman, R. (2009). Population Growth Steady in Recent Years. Washington: Worldwatch Institute.

Epstein, P., Buonocore, J., Eckerle, K., Hendryx, M., Stout III, B., Heinberg, R., ... Glustrom, L. (2011). Full cost accounting for the life cycle of coal. Ecological Economics Reviews, 1219(2), 73-98. http://dx.doi.org/10.1111/j.1749-6632.2010.05890.x

Field, A. (2009). Discovering statistics using SPSS (3rd ed.). London: Sage.

Filho, L. (2011). About the Role of Universities and Their Contribution to Sustainable Development. Higher Education Policy, 24, 427-438. http://dx.doi.org/10.1057/hep.2011.16

Fishbein, M., \& Ajzen, I. (2010). Predicting and Changing Behaviour. The Reasoned Action Approach. New York: Psychology Press.

Ginsborg, P. (2005). The Politics of Everyday Life. Making Choices Changing Lives. London: Yale University Press.

Goleman, D. (2009). Ecological Intelligence. How Knowing the Hidden Impacts of What We Buy Can Change Everything. New York: Broadway Books.

Graham, C. (2011). The pursuit of happiness. An economy of well-being. Washington: Brookings Institution Press.

Haavisto, I., \& Kiljunen, P. (2011). Maailman paras maa. EVAn kansallinen arvo- ja asennetutkimus. Helsinki: Taloustieto Oy.

Haberl, H., Fischer-Kowalski, M., Krausmann, F., Martinez-Alier, J., \& Winiwarte, V. (2011). A Socio-metabolic Transition towards Sustainability? Challenges for Another Great Transformation. Sustainable development, 19(1), 1-14. http://dx.doi.org/10.1002/sd.410

Haque, U. (2011). Betterness: Economics for Humans. Harvard: Harvard Business Press.

Haughton, G. (1999). Environmental justice and the sustainable city. Journal of Planning Education and Research, 18, 233-243. http://dx.doi.org/10.1177/0739456X9901800305

Hawken, P. (2010). Declaration of sustainability. In David Keller (Ed.), Environmental ethics - the big questions (pp. 509-515). New York: Wiley-Blackwell.

Hawken, P., Lovins, A., \& Lovins, L. (2010). Natural Capitalism: The Next Industrial Revolution. London: Earthscan.

Herren, H. (2011). Innovations in understanding complex systems. In State of the World 2011 (Ed.). Innovations that nourish the planet (pp. 166-168). Washington: The Worldwatch Institute.

Hofstede, G., Hofstede., G. J., \& Minkov, M. (2010). Cultures and Organizations, Software of the Mind. Intercultural Cooperation and its Importance for Survival. London: McGraw-Hill. 
IEA. (2009). World Energy Outlook Report 2009. Executive summary. Paris: International Energy Agency. Retrieved from http://www.iea.org/textbase/npsum/weo2009sum.pdf

IEA. (2011). Clean energy Progress Report. IEA input to the Clean Energy Ministerial. Paris: International Energy Agency. Retrieved from www.iea.org/papers/2011/CEM_Progress_Report.pdf

Iqbal, S., Guggenberger, M., \& Khorshed, A. (2012). Deadly Denim. Sandblasting in the Bangladesh Garment Industry. Amsterdam: Clean Clothes Campaign.

Jackson, T. (2005). Motivating Sustainable Consumption. A review of evidence on consumer behaviour and behavioural change. A report to the Sustainable Development Research Network. Guildford: University of Surrey.

Jackson, T. (2009). Prosperity without growth. Economics for a finite planet. London: Earthscan.

Jurin, R., \& Fortner, R. (2002). Symbolic Beliefs as Barriers to Responsible Environmental Behav-ior. Environmental Lifelong Learning Research, 8(4), 373-394.

Kahneman, D., Krueger, A., Schkade, D., Schwarz, N., \& Stone, A. (2006). Would you be happier if you were richer? A focusing illusion. Science, 312(5782), 1908-1910. http://dx.doi.org/10.1126/science.1129688

Kasser, T. (2011). Cultural Values and the Well-Being of Future Generations: A Cross-National Study. Journal of Cross-Cultural Psychology, 42(2), 206-215. http://dx.doi.org/10.1177/0022022110396865

van de Kerk, G., \& Manuel, A. (2006). The Netherlands, a sustainable society? The Index for a Sustainable Society. Amsterdam: Uitgeverij De Vijver.

Kollmuss, A., \& Agyeman J. (2002). Mind the Gap: Why do people act environmentally and what are the barriers to pro-environmental behavior? Environmental Lifelong learning Research, 8(3), 239-260.

Koskela, M. (2008). Ympäristöasenteet ja -toiminta kuntaorganisaatioissa. Espoon, Helsingin, Jyväskylän, Oulun, Tampereen, Turun ja Vantaan kaupungit. Turku: Tulevaisuuden tutkimuskeskus ja Turun kauppakorkeakoulu.

Kluckhohn, F., \& Strodtbeck, F. (1961). Variations in Value Orientations. Evanston, IL: Row, Peterson.

LaSalle, T., \& Hepperly, P. (2008). Regenerative Organic Farming: A Solution to Global Warming. Rodale Institute. Retrieved from www.rodaleinstitute.org/files/Rodale_Research_Paper-07_30_08.pdf

Laszlo, E. (1996). The systems view of the world. A holistic vision for our time. Cresskill: Hampton Press.

Lawn, P. (2003). A theoretical foundation to support the Index of Sustainable Economic Welfare (ISEW), Genuine Progress Indicator (GPI) and other related indexes. Ecological Economics, 44(1), 105-118. http://dx.doi.org/10.1016/S0921-8009(02)00258-6

Lobley, M., Butler, A., \& Reed, M. (2009). The contribution of organic farming to rural development: An exploration of the socio-economic linkages of organic and non-organic farms in England. Land Use Policy, 26(3), 723-735. http://dx.doi.org/10.1016/j.landusepol.2008.09.007

Markandya, A., \& Wilkinson, P. (2007). Electricity generation and health. The Lancet, 370(9591), 979-990. $\mathrm{http}: / / \mathrm{dx}$.doi.org/10.1016/S0140-6736(07)61253-7

Marglin, S. (2008). The Dismal Science. How Thinking Like an Economist Undermines Community. London: Harward University.

Marks, N., Abdallah, S., Simms, A., \& Thompson, S. (2006). The Happy Planet Index, An Index of Human Well-being and Environmental Impact. London: New Economics Foundation.

Meadows, D., Meadows, D. L., \& Randers, J. (2004). Limits to Growth. The 30-Year Update Revised Edition. London: Earthscan.

Miller, T., \& Spoolman, S. (2009). Living in the environment: principles, connections, and solutions (16th ed.). Cole: Brooks.

Munasinghe, M. (2011). Millennium consumption goals (MCG): How the rich can make the planet more sustainable. The Island Online January 31. Retrieved from www.island.lk/index.php?page_cat $=$ article-details\&page $=$ article-details\&code_title $=17248$

Nellemann, C., MacDevette, M., Manders, T., Eickhout, B., Svihus, B., Gerdien Prins, A., \& Kal-tenborn, B. (2009). The environmental food crisis, The environment's role in averting future food crises. A UNEP rapid response assessment. United Nations Environment Programme. 
Nordic Council. (2009). Sustainable Development - New bearings for the Nordic Countries. Stockholm: Nordic Council of Ministers.

Nussbaum, M. (2010). Not for Profit. Why Democraties Needs the Humanities. Princeton: Princeton University Press.

Osgood, C., Suci, G., \& Tannenbaum, P. (1957). The Measurement of Meaning. Chicago: University of Illinois Press.

Pongratz, J., \& Caldeira. K. (2012). Attribution of atmospheric $\mathrm{CO}_{2}$ and temperature increases to regions: importance of preindustrial land use change. Environmental Research Letters, 7(3), 1-9. http://dx.doi.org/10.1088/1748-9326/7/3/034001

Patton, M. (2002). Qualitative research \& evaluation methods (3rd ed.). London: Sage.

Prescott-Allen, R. (2001). The Wellbeing of Nations. A country-by-country index of quality of life and the environment. London: Island Press.

Prime Minister's Office Publications. (2006). Towards sustainable choices. A nationally and globally sustainable Finland. The national strategy for sustainable development. Prime Minister's Office Publications 2006/7.

Reardon, S. (2012). Will we ever be able to buy a fair-trade smartphone? New Scientist 2860, 18. http://dx.doi.org/10.1016/S0262-4079(12)60950-6

Rees, W. (2010). What's blocking sustainability? Human nature, cognition, and denial. Sustainability: Science, Practice, \& Policy, 6(2), 13-25. Retrieved from http://www.google.fi/archives/vol6iss2/1001-012.rees.html

Reganold, J. (2010). The next revolution in farming. Scientific American, 303(3), 97.

Raworth, K. (2012). Planetary Boundaries and Social Boundaries: Defining a Safe and Just Operating Space for Humanity. Oxford: Oxfam.

Ryan, G., \& Bernard, R. (2000). Data management and analysis methods. In Denzin, N., \& Lincoln,Y. (Eds.). Handbook of Qualitative Research (pp. 769-793). London: Sage.

Sale, P. (2011). Our Dying Planet. An Ecologist's View of the Crisis We Face. Los Angeles: University of California.

Schwartz, S. (1992). Universals in the content and structure of values, Theoretical advances and empirical tests in 20 countries. Advances in experimental social psychology, 25(1), 1-65. http://dx.doi.org/10.1016/S0065-2601(08)60281-6

Shafer-Landau, R. (2010). The Fundamentals of Ethics. New York: Oxford University.

Sen, A. (2009). The Idea of Justice. Cambridge: Harward University.

Stern, P. (2000). Toward a coherent theory of environmentally significant behavior. Journal of Social Issues, 56(3), 407-424. http://dx.doi.org/10.1111/0022-4537.00175

Stern, P. (2005). Understanding Individuals' Environmentally Significant Behaviour. ELR News \& Analysis, 35, 10785-10790.

Stiglitz, J., Sen A., \& Fitoussi, J-P. (2009). The Measurement of Economic Performance and Social Progress Revisited. Reflections and Overview. Commission on the Measurement of Economic Performance and Social Progress. Retrieved from www.stiglitz-sen-fitoussi.fr/en/documents.htm

Swim, J., Clayton, S., Doherty, T., Gifford, R. Howard, G., Reser, J., ... \& Weber, E. (2009). Psychology and Global Climate Change: Addressing a Multi-faceted Phenomenon and Set of Challenges. A Report by the American Psychological Association's Task Force on the Interface Between Psychology and Global Climate Change. Washington, D.C.: American Psychological Assosiation.

UN. (1992). Agenda $21 \quad$ Program. www.un.org/esa/sustdev/documents/agenda21/english/agenda21 toc.htm\#sec3

UN. (2011). World Population to reach 10 billion by 2100 if Fertility in all Countries Converges to Replacement Level. Press Release 3rd May 2011. Retrieved from http://esa.un.org/unpd/wpp/Other-Information/Press_Release_WPP2010.pdf

UNDP. (2008). Human Development Report 2007-2008. Fighting climate change. Human solidarity in a divided world. New York: United Nations Development Programme. 
U.S. Department of Labor. (2009). List of Goods Produced by Child or Forced Labor. Trafficking Victims Protection Reauthorization Act of 2005. Washington: Bureau of International Labor Affairs. Retrieved from www.dol.gov/ilab/programs/ocft/PDF/2009TVPRA.pdf

Weinreich, N. (1999). Hands-On Social Marketing: A Step-By-Step Guide. London: Sage.

Wenz, P. (1988). Environmental Justice. New York: Suny.

Note

Note 1. An earlier version of this paper was presented in the American Educational Research Association (AERA) Annual Meeting 2012, April 13-17, Vancouver, British Columbia, Canada: Salonen, A. \& Ahlberg, M. (2012). Personal and Contextual Barriers to the Promotion of Sustainable Development in Everyday Life. 